\title{
Supporting rule of law from abroad. A comparative assessment of two post-Arab Spring judicial reforms
}

\begin{tabular}{|c|l|}
\hline Journal: & Italian Political Science Review \\
\hline Manuscript ID & IPSR-RA-2018-0021.R3 \\
\hline Meywords: $:$ & $\begin{array}{l}\text { Judicial system, Comparative Politics, European Union, Policy analysis, } \\
\text { Middle East }\end{array}$ \\
\hline Abstract: & $\begin{array}{l}\text { In the Southern Mediterranean region the European Union (EU) supports } \\
\text { the establishment of rule of law, pressuring for both the adoption of } \\
\text { institutional guarantees of judicial independence and the enhancement of } \\
\text { court administration capabilities. Drawing on a set of interviews with key } \\
\text { EU and domestic actors, this study compares Morocco and Jordan, } \\
\text { examining changes adopted at the institutional and administrative level } \\
\text { since the 'Arab Spring' broke out. The findings show that external } \\
\text { incentives for change penetrated only the administrative level of } \\
\text { domestic judicial systems, while a path-dependent effect persisted at the } \\
\text { institutional level. The evidence confirms the thesis that in areas of low } \\
\text { politics even a mere normative pressure is able to drive rule adoption, } \\
\text { whereas in more sensitive policy areas, as in the case of institutional } \\
\text { judicial guarantees, the higher costs of adaptation make veto players } \\
\text { resistant to external influences for change. }\end{array}$ \\
\hline
\end{tabular}

\section{SCHOLARONE Manuscripts}




\section{Supporting rule of law from abroad. A comparative assessment of two post-Arab Spring judicial reforms}

In the Southern Mediterranean region the European Union (EU) supports the establishment of rule of law, pressuring for both the adoption of institutional guarantees of judicial independence and the enhancement of court administration capabilities. Drawing on a set of interviews with key EU and domestic actors, this study compares Morocco and Jordan, examining changes adopted at the institutional and administrative level since the 'Arab Spring' broke out. The findings show that external incentives for change penetrated only the administrative level of domestic judicial systems, while a path-dependent effect persisted at the institutional level. The evidence confirms the thesis that in areas of low politics even a mere normative pressure is able to drive rule adoption, whereas in more sensitive policy areas, as in the case of institutional judicial guarantees, the higher costs of adaptation make veto players resistant to external influences for change.

Key words: rule of law, judicial policies, European judicial support, Euro-Mediterranean relations, comparative analysis

\section{Introduction}

The European Union (EU) has, since the outset of the Euro-Mediterranean Partnership, developed instruments of foreign policy that promote and support democracy in the countries of the Southern Mediterranean Neighbourhood. A number of programs specifically addressed rule of law and the judiciary in order to strengthen judicial independence and enhance the efficiency of the courts. In order to preserve stability as the 'Arab Spring' broke out, two monarchies in the region, Morocco and Jordan, faced the need to reform their judicial systems with constitutional reforms that would deliver them from poor guarantees of judicial independence, lack of transparency and inefficiency in the court system. 
The dynamic of European influence in supporting rule of law through judicial reforms in nonEuropean countries is an empirical puzzle, a significant issue being the capacity of EU rule of law promotion to affect transformation in domestic institutions. The literature suggests that, when dealing with neighbouring countries, lack of membership perspective and credible conditionality leads to a weak domestic impact by the EU when compared to the experience of Eastern enlargement (Gawrich et al. 2009; Börzel 2011; Schimmelfennig and Sedelmeier 2005).

This article contributes to the literature on Europeanisation and European external action and looks at the reorganisation of the judicial systems of two recipient countries in the MENA (Middle East and North Africa) region. In doing so, it provides new insight on the dynamics of externally promoted judicial reforms and domestic changes. To what extent were European judicial standards able to curb domestic reforms in non-EU countries? Do judicial reforms adopted in Morocco and Jordan converge toward a similar model? Which EU standards of governance entered their domestic systems? By addressing these questions, this article aims to better understand externally supported judicial reforms in the promising yet under-investigated empirical field of the judiciaries of MENA countries post2011 reforms, and the EU's role.

This article falls in the field of studies that explores the EU's promotion of democracy beyond its borders and the interaction between European and domestic actors. This strand of literature notes that the lack of membership perspective hampers the capacity of the EU to promote transformation in neighbouring countries (Vachudova 2005; Schimmelfennig 2005; Börzel and Risse 2012). The main problem resides in what Börzel defines as 'prohibitive costs but little pressure for adaptation' (Börzel 2011: 403), meaning that the changes agreed by the EU and European Neighbourhood Policy (ENP) countries pose major costs to veto players (Börzel and Risse 2012) while the rewards might be too low, especially with no perspective of membership. The EU has, moreover, been very reluctant to use credible conditionality - such as simplified visa regimes and trade agreements - as well as negative conditionality (Lavenex and Schimmelfennig 2008; Youngs 2009). The issue of conditionality is best exemplified in a model proposed by Schimmelfennig and Sedelmeier. It distinguishes between an external incentives model, where change is expected because conditions are consistent and clear and 
adoption costs are low, and a social learning model, where norms and rules are adopted because they are deemed appropriate (Schimmelfennig and Sedelmeier 2005; Sasse 2008). In the peculiar relationship between the EU and European Neighbourhood Policy (ENP) countries, the main element of conditionality is vague and relies on the mechanism of socialisation. The conditionality element appears even less concrete in the judicial realm. In the absence of binding norms to be transposed, the EU has, over time, developed a number of standards deployed in judicial support programmes financed through the ENP instrument, soft policy instruments such as twinning, technical assistance and information exchange (TAIEX), and training programmes, that enact the mechanism of socialisation. Scholars who investigated EU-promoted judicial reforms in eastern European countries demonstrated how the effects of Europeanisation varied among policy sectors and countries. Notably, pre-accession institutional frameworks were not changed by the EU accession process (Coman 2013; see also Papadimitriou and Phinemore 2004; Grabbe 2001).

Our study contributes to this strand of Europeanisation literature offering valuable insight on the differential trend that EU policies of judicial promotion have had in Southern Neighbourhood countries. We show that, while the judicial administrative dimension is open to external incentives for change, the institutional dimension is resistant to any external model and rather moves along domestic paths of reform. The effect of European judicial promotion in the Southern Neighbourhood is in the hands of domestic rather than European actors. In operationalising rule of law and judicial governance we draw upon a multidimensional definition (Carothers 1998; Magen and Morlino 2008; Piana 2011) that recognises at least two dimensions as necessary conditions for the enforcement of rule of law: judicial independence and quality of justice. Indeed, while the paradigm of rule of law and its promotion is strictly interlaced with the pivotal aspect of judicial independence (Guarnieri and Piana 2011) and is centered on formal guarantees of judicial impartiality - which in the EU's promotion effort mostly means the introduction of an independent High Judicial Council (HJC) - the other dimension takes into account the efficiency of the court systems (Piana 2011). In light of this and for the sake of operationalisation we will refer to an institutional and an administrative level. The argument proposed resonates well with the rational choice institutionalist approach. This approach maintains that the EU enables domestic change, shifting 'opportunity structures' (Börzel 2001: 396) 
for domestic actors and then taking veto powers to domestically adopt the external models offered (Börzel and Risse, 2012). In the absence of resistance by veto players ${ }^{1}$ the literature shows that beneficiary countries are open to externally-supported changes (Morlino and Magen 2008). Therefore, given the low conditionality and mechanism of socialisation in place, the EU is not able to curb changes on the systemic level of the judiciary in countries that are undergoing democratic reforms. In fact, the creation or enforcement of the independence of the HJC is costly for veto players; at this level, we demonstrate that changes followed a path dependence more than external incentives for reforms. On the other hand, we show the positive reception of non-systemic judicial inputs both in Morocco and Jordan that pertain to the administrative level, also given the lack of cost that this entails for veto players.

Analytically we consider the cognitive component of the process of rule adoption, the set of beliefs considered 'hard core' that underlie the choice of a policy (Capano 2003: 783). We maintain that policy adoption happens at the level of ideas by relevant political actors and not only at the structural level. The level of ideas, also defined as 'policy paradigms' (O'Sullivan 1999), has been considered as influencing policy change in external European policy (Schimmelfennig and Sedelmeier 2005:7). Therefore, given the impossibility at this stage of the reforms to assess the adoption of EU rules in Morocco and Jordan, we focus on the first stage of the policy-making process, relying on the resistance encountered - or not - by EU rules and norms in domestic systems.

The following two sections focus on judicial reforms in Morocco and in Jordan. They highlight EU support and the programmes enacted in the last decade, describing the role of veto players and ideational components in both cases, and making a distinction between institutional and administrative judicial reforms. A third section compares the two cases and focuses on the different distribution of powers between King, executive and judiciary. In doing so, we will show the path dependent effect that persisted in the institutional dimension. The conclusion will sum up our

\footnotetext{
${ }^{1}$ Veto players are here defined as individual actors who are de facto actors of judicial systems and whose agreement is required for a change in the status quo (Tsebelis, 1995)
} 
findings. The empirical research is complemented by seven semi-structured interviews conducted between 2017 and 2018 with EU programme experts, beneficiary state representatives, magistrates and EU functionaries.

\section{The 'New Era' and the role of the EU}

In Morocco no real changes in the distribution of powers between the legislative, executive and judiciary characterised the country's modern history, where a lack of checks and balances in favour of the executive and the King persisted over time. With the 'New Era'- which began with the accession to the throne of King Mohammed VI in 1999 - a cycle of openness toward democratic initiatives started. In the same manner, the first phase of EU-Moroccan relations began, even if the empirics show no substantial use of EU programmes directed towards the Justice and Home Affairs (JHA) policy sector in the first phase. Indeed, when the 'New Era' started, EU-Mediterranean policy was developing and Morocco appeared to be one of the more prominent partners from the start of the Barcelona Process.

The first Euro-Moroccan cooperation on JHA matters started with the MEDA programme, a basic financial instrument established for the period 1995-2006 and linked with the Euro-Mediterranean Partnership launched at the Barcelona Process in 1995. The assistance provided to Morocco under the MEDA totalled 1.6 billion Euros during the period 1995-2006 (Natorski 2008). It was only under MEDA II that clear support to 'justice' appeared; the second tranche of finance of 15 million Euros for the period 2005-2006 clearly addressed, among several issues, JHA in Mediterranean relations. In 2000, the Association Agreement between the EU and Morocco was signed; within this framework the importance of an independent and efficient judiciary constituted a central pillar. In particular, the cooperation itself was made conditional upon the respect of such fundamental pillars and the enhancement of relations with the EU. The Action Plan between the European Commission and Morocco in 2011 recognised that year as a turning point for the country; indeed, the King's speech of 9 March marked the start of a comprehensive constitutional reform that would have provided for democratic changes in the country. In particular, the Annual Progress Report of the EU positively saw the new Constitution 'as putting in place a new legal framework that guarantees human rights and 
considers justice as a power and not only as an authority' (Morocco Progress Report 2011). The Commission also recognised that 'Justice remains a challenge in order to establish rule of law and consolidate the credibility of the reforms. The EU thus signaled that it stands ready to support the reform process once the content of the reform will be detailed' (Ibid.).

\section{1: The turning point for the Moroccan judiciary}

The turning point in Morocco's judiciary began at the end of 2010, when two different demands converged and a phase of progressive changes for the country started. While for the political elite and the King reforms were sought in order to combat corruption and enhance judicial capabilities, for political activists, civil society stakeholders and political opponents, as well as international observers, demands for reforms also focused on the establishment of minimal guarantees of judicial independence. These two demands converged in the aftermath of the February 2011 protest movements. The February Movement specifically addressed the need to combat widespread corruption in the country, to achieve social justice and finally implement reforms within which a comprehensive revision of the judiciary should be initiated. The immediate response of the King was to agree to a comprehensive review of the Constitution and the creation of a Consultative Commission for the Revision of the Constitution. In this sense, the organic law for reforming the judiciary represented the first concrete outcome of a long process of pushing for judicial reforms that had already started a decade before 2011 (Terms of Reference 2015 : 3). An early reaction was directed towards the delay in issuing an organic law for the establishment of the HJC. Other concerns were raised about the inefficiency of the judicial system as a whole: slow execution of sentences, poor preventive detention methods and a shortage in human resources as well as their redistribution. The inefficiency of the judicial system in Morocco was also highlighted by international observers (ICJ Report 2015), who recognised the need to amend the organic law on the Conseil Supérieur du Pouvoir Judiciaire (CSPJ) in order to meet international standards, in particular regarding the competences of the new Judicial Council over judicial administration and the selection of training judges. This notwithstanding, the organic law on the new CSPJ was adopted on 16 March 2016, with pressure also 
coming from the EU which made the disbursement of the first tranche of the Judicial Support Programme conditional on the passing of the law.

The constitutional revision of Chapter 7, Articles 107-112, established a system of constraining of judicial power: that judicial independence from legislative and executive power be provided (Art. 107), that the dismissal and transfer of judges be made in accordance with the law (Art. 108), that the independence of judges be respected and that judges report injunctions to their responsible authorities to the High Council of the Judicial Power (Art. 109), that judgments be made in accordance with the law (Art. 110), that judges may join associations and establish professional unions (Art. 111) and that the statute of judges be established by an organic law (Art. 112). Even if financial conditionality was applied by the EU to the legal drafting of a new CSPJ, the institutional set-up was internally driven. The high legitimacy of the domestic political elite worked as the main actor for the full adoption of an independent judicial council, more than the EU cooperation. In fact, the Moroccan CSPJ was not modelled along European standards; rather, the reform can be read as an anticipation of further judicial cooperation with external donors, as the EU disbursement condition shows. The new law on the CSPJ provides for a judicial council that does not have the same functions as the French Conseil Supérieur de la Magistrature (CSM) ${ }^{2}$ nor the Spanish system, these two European countries being the most engaged in judicial cooperation with Morocco (Interview 5). Only certain features of the western models appear in the new constitutional amendments; it is clear that some aspects appealed to potential veto players while others were downplayed. In fact, the King remains the President of the High Judicial Council with the power to nominate and appoint judges. It is not possible, however, to observe a European model adopted in the new configuration of the CSPJ that is 'A singular Marocain

\footnotetext{
2 The French CSM was established in 1946. This Council is structured according to the Southern European Model, but has some peculiarities when compared with the Councils of Southern European democracies that experienced authoritarianism and that show a stronger insularity of the judiciary vis-à-vis other branches of the State (Piana 2011: 20). The President of the Republic of France chairs the Council, half its members are appointed from judicial organisations and the Public Prosecutor's Office; one member is appointed by the President of the Republic and the rest by the Parliament. The French CSM appoints members of the judiciary, disciplines judicial procedures and promotes members of the judiciary. In contrast, the Spanish General Council is similar in its composition but has more discretionary power from the Government and the Ministry of Justice, such as training and supervision via inspection (Voermans 1999).
} 
Model' (Zaatit, La Tribune Politique, 4 April 2018). This is also in line with the aim of the EU's leading nation supporting judicial reforms in the country, France: 'We defend the idea that judicial cooperation should start from the need expressed by Morocco and then to orient the strategy accordingly' (Interview 5). In particular, it is evident that Morocco chose to move from the former CSM toward the CSPJ, a move toward a more independent institution giving the judiciary the status of power as opposed to authority and not resembling the model of the French CSM (Interviews 5 and $3)$.

The distribution of power between the institutional and administrative judicial dimensions that came out from the reforms of the post-2011 explains the subsequent rounds of organizational changes. In this sense, European external pressure is a leeway that strengthened a process of judicial reform that responds to a domestic logic of action rather than an external one. These reforms, and in particular the creation of the CSPJ, seem to respond to a domestic need for change even if they were implemented under the Agreement with the EU, but without a direct program of judicial support. For this reason, the CSPJ reform can be read as an anticipation of future cooperation expected by Moroccan actors in response to EU engagement.

Table 1 Timeline, Morocco's judicial reforms and European inputs -here-

\section{How European inputs enter Morocco's judicial administrative organization}

With regard to external inputs, substantial EU pressure arrived only in 2014, when the program of support for the justice sector - Convention de Financement d'appui à la réforme de la Justice - was decided, and then finally signed in December 2015. From this point on, European standards and good practices gained access to the changing and porous judicial system of Morocco. The external 'anchoring' (Morlino and Magen 2008) is made through the establishment of linkages between political actors involved in the judicial reform process, magistrates and judicial practitioners. In this sense, the payload of the European Judicial Support project, with a budget of 75.5 million Euros 
distributed over a period of five years, represents the most significant attempt of support directed to the justice sector financed by the EU in Morocco in the last two decades. The inputs coming from the West address: Judicial Independence, Access to Justice, Judicial Protection and Human Rights, Efficiency and Efficacy of Justice (Terms of Reference 2015). The condition for the disbursement of the fixed tranche of the project was the promulgation of two organic laws establishing the creation of the CSPJ and the Statut des Magistrats (Ibid.).

The external European inputs entered the Moroccan domestic judiciary in relation to the Judicial Academy (Administrative Dimension). In this realm, the 'supply side' of judicial inputs (Piana 2009: 102) in Morocco is captured by French legal experts and to a limited extent by Spanish and Belgian practices. The program's main objective is to contribute to the judicial reform enacted by the Ministry of Justice in order to enhance the efficacy of the judicial system. With this program the EU intends to provide expertise and technical aids to the Ministry of Justice (MoJ), CSPJ, Public Prosecutor's office with a view to supporting the Ministry of Justice in putting into place all the actions planned in the judicial reform. In particular, the expected results deal with a truly operational CSPJ, the establishment of a commission between the MoJ and CSPJ for all questions regarding judicial administration respecting the separation of powers as written in the new Constitution, strengthening access to justice and enhancing the efficiency, in particular through training professionals and technicians in modern techniques. Within this program the first operational project is the technical assistance Twinning established in 2017 and directed towards the Ministry of Justice. This activity will last for 34 months and is divided between long technical missions, medium and short workshops, expert evaluations and seminars. The inputs the French Ministry of Justice and the Justice Cooperation Internationale (JCI), the operative institution of the French Ministry of Justice. A characteristic of Twinning is that EU best practices - in this case in the realm of judicial governancerely on EU experts who come from different public administrations of member states; this is also the case in the Twinning program of support to the Institut Supérieur de la Magistrature ( ISM), of Morocco (Interview 1). 
At the European level, there is not a single EU judicial model addressing how judicial training is organized, but a main feature of western states is the high specialization of courses, in particular the separation of training provided to magistrates, lawyers and administration officers or clerks.

\section{Twinning with France}

In the Twinning project financed under the ENPI program of the Institut Supérieur de la Magistrature (ISM), France is the leading country, with Spain and Belgium acting as junior partners in the support given to the institutional reform of the ISM. Morocco, and more generally the Maghreb region, represents a priority region for French cooperation programs, and judicial support is a fundamental pillar of French international cooperation (JCI Rapport D'Activité 2017: 4). In particular, after 2015 the operational agency of the French Ministry of Justice, the JCI, engaged in a number of projects aimed at accompanying reforms started in the region towards democratic transition and institutional reforms (Ibid.).

The EU has pushed for the reinforcement of the capacity of the Judicial Academy, the ISM, in order to assure an effective judicial reform that is in line with the exigencies of the Acquis, an efficient and independent judiciary, and of the good practices of the EU. Morocco in this sense had more to ask in terms of efficiency given that comprehensive judicial changes had already started in 2011. Moreover, while some of the rules concerning judicial independence have already been adopted, the administrative dimension was ready to receive technical support from international donors. The technical aids only arrived in 2017 and the European partners represent the channel through which a new organigram, human resources, training curricula and communication of the new Judicial Academy are going to be introduced to the Moroccan judicial system.

The Judicial Academy model of western countries is characterized by a deep level of specialization. In particular, two different schools provide for specialized and differentiated training to judges and clerks; this model appears highly efficient and attracts the support of the Minister of Justice and the King who already in 2009 insisted on the need to 'upgrade human resources, training and evaluation of the judicial system' (King Mohammed VI, 20 August 2009) of the Moroccan Judicial Academy. Indeed, with the creation of the CSPJ the legislator was confronted with a new issue: a proposal was 
made to move the Judicial Academy under the control of the new Judicial Council but it was immediately realized that a problem of efficiency characterized the ISM in that it trained not only judges but also clerks, notaries and lawyers (Interviews 3 and 4). The training provided to magistrates and clerks indeed was, before the judicial reforms adopted in 2013, also considered non-sufficient by international observers; the World Bank assessment of the Judiciary of Morocco (World Bank 2003) addressed the need to reconsider the capacity of the ISM in light of its limited capacity to provide extensive training to judges and clerks. A new training system for Moroccan judges and clerks was also addressed by civil society stakeholders who, as soon as the Constitution was effective, started to examine the condition of the judiciary in Morocco and came up with a set of recommendations for reforming the judiciary in general and also the court system based on the new rights gained under the new Constitution.

Citing Cobb, Ross and Ross (1976) on the typology of Agenda Setting, the need for a more effective Judicial Academy in Morocco follows a true 'mobilization model' (Cobb, Ross and Ross 1976) where the issue enters the agenda not only through inner political circles, in this case the Royal circle and the Minister of Justice, but also through a wider engagement of actors such as civil society activists as well as external collective observers. It is without doubt that the issue of an efficient way of training magistrates was accepted and required by a wide range of political actors. In this sense, the functional cooperation of the Twinning program is the means through which European standards of Judicial Academies enter the domestic system of Morocco.

Technical assistance is going to be organized through a number of meetings with French experts sur place that will directly address the needs expressed by the Moroccan Ministry of Justice that coordinates the activities of the ISM (Interview 5). The meetings will focus on the best organizational set-up of a more effective Judicial Academy, whether that be creating different schools for judges and clerks or providing different and more specialized courses (Ibid.). Two senior experts and three juniors are designated by the Twinning project and they will work in close cooperation with the office in the Ministry of Justice in Rabat and the Directorate of the ISM (Term of Reference 2015). In particular in the first stage, the aim of the experts is to support the changes taking place at the level of the institutional set-up of the ISM as well as with the modernization of the curriculum. In this way 
expert meetings and training the trainers are, in the first phase of the project, the activities organized by French legal experts in order to help structure the organigram of the new Judicial Academy that will provide a more specialized training for magistrates and clerks, as the main issue that appeared after the creation of the CSPJ was related to the low specialization of training (Interview 3).

It is noteworthy to stress that technical aid is not going to provide Morocco with a copy of the French ISM model; instead, counselling is provided on specific issues deemed compelling by the General Directorate of the Moroccan ISM (Interviews 3 and 4). The changes introduced by the Twinning will not touch upon the distribution of power between the MoJ and the HJC with relation to training, but the external inputs are able to influence the management of the Judicial Academy is organized in order to create a more efficient way of dealing with training judges, prosecutors and clerks.

\section{Constitutional reforms in Jordan: the status of the judiciary}

Jordan has been defined as the 'presidential monarchy' par excellence among the monarchies of the MENA region due to the prerogatives that the King was able to maintain despite democratic concessions given in the wake of the Arab Spring (Biagi 2018: 387). Jordan typifies - better than Morocco - the main features of the Islamic states: 'an unchecked executive and a strong concentration of powers in the Head of the State', being in this case the King (Feldman 2008). Most interestingly, Jordan was able to maintain those two prerogatives through the regional destabilization of 2011 and through the subsequent constitutional reform, thus signaling a great degree of continuity with the past when compared to Morocco. However, in this picture judicial power represents a discontinuity. Keeping in mind that Jordan's last wave of reform has to a great extent centralized even more powers in the hands of the King, it must be acknowledged that important steps were made in the judicial realm that saw a reinforcement of guarantees of independence as well as of efficiency.

As in the case of Morocco, Jordan established good relations with the European Community (EC) first and later the EU, making the cooperation institutionalized as the process of integration of the EU's foreign policy developed. The Association Agreement was signed and finally entered into force in 2002. The last step is ultimately reached with the inception of the ENP, when the European Union 
and Jordan adopted an Action Plan in 2005 marking the final milestone of their bilateral cooperation. The European Commission started therefore to monitor the developments of the implementation of the pillars on which the Action Plan was built. In the Action Plan it is stated that a key priority is 'the enhancement of independence and impartiality of the judiciary and its administrative capacity' (Jordan Action Plan 2005).

As in Morocco, the phase of modernization for Jordan began in 1999 with the death of King Hussein and the accession to the throne of King Abdullah II. The King launched a comprehensive plan for the development of the country; in the judicial realm, a Royal Committee for Judicial Development was established and a plan drawn up that mostly consisted of efficiency-inspired reforms (World Bank Legal Review 2014: 246). The plan was developed in two main tranches and saw a number of achievements that provided for the modernization of the judicial system, such as the automation and computerization of the functions of the Ministry of Justice, the modernization of systemic procedures within the Executive branch and the enhancement of human resources in the administration of the courts. The second tranche, 2007-2009, saw in particular the revision of the Law of Independence of the Judiciary (JIL), the beginning of the works on the draft law of the Judicial Authority and the strengthening of computerization and judges' skills (Ministry of Justice Strategy, 2014-2016). Therefore, for what concerns the five-year strategy prior to the Arab Spring, Jordan achieved a number of developments in the justice sector, in particular the modernization of the judicial system and a innovations such as the preparation of the draft law on the Constitutional Court, the Judicial Independence Law, the Independent Electoral Commission draft law and the Administrative Judicial Law. The Judicial Independence Law (JIL) represents a great achievement for Jordan's judicial reform process (Interview 6). Approved firstly in 2001, in its initial first version the law did not conceive the creation of an independent Judicial Council; that was only created with the amendments of 2011, in the wake of the protests (Ibid.). The Judicial Upgrade Strategy (JUST) was a direct response to the work of the first Royal Committee for Judicial Upgrading (World Bank Legal Review 2014: 247). JUST followed the recommendations of the Committee that were directed towards efficientist reforms such as: the increasing of the number of judges, automatization of case 
management procedures, simplification of court proceedings through legislative amendments, and division between the courts in order to enhance the management of civil cases.

\section{8: The EU enters Jordan's reform stream}

The EU began to actively support judicial reforms in Jordan in 2008, when the ENPI program of Judicial Support 'Support to Justice Reform and Good Governance in Jordan' was enacted. The program kicked off at the precise moment of the Jordanians' reform path. Indeed, the EU recognized that the Jordanian government had undertaken a number of steps towards the establishment of rule of law and the enactment of good governance practices such as 'the adoption and implementation of a judicial strategy JUST, the establishment of an Anti-Corruption Commission and the adoption of the Amman Message to counter radicalisation' (Fiche ENPI 2008). The EU recognized the positive path undertaken while acknowledging the need for further technical aids in particular to support the upgrade of legal and regulatory frameworks of criminal justice (Ibidem).

The ENPI of 2008 was made conditional upon the implementation of the JUST strategy and of the National Agenda. The program was designed around a number of objectives: supporting the Ministry of Justice in implementing the criminal justice reform in line with international standards, strengthening the juvenile justice system, supporting the newly established Anti-Corruption Commission in implementing anti-corruption strategy and supporting the objectives of the Amman Message. The European action of 2008 was specifically directed toward the support of the ongoing strategy of the Government and of the King's path toward modernization to enhance the efficiency of the judicial system, to provide for an efficient and effective administration of the courts and to support new legislation in criminal matters. Conversely, the European program was not designed to act directly in the institutional dimension of Jordan's judiciary that, in the pre-2011 era, was not on the radar of the reforms. The EU's action did not touch upon the institutional dimension of Jordan's judiciary but assisted the ongoing domestic reform process of legislative and administrative enhancement.

\section{1: The turning point for Jordan's reform path}


The literature recognizes 2011 as a step that further strengthened the power in the hands of the King versus the Parliament in Jordan, but also that the prerogatives of the Government were increased, not providing for a true separation of powers. Biagi noted as emblematic that Chapter 4, Article 1 of the amended Constitution dedicated to 'The King and His Prerogatives' was not altered (Biagi 2018: 389; Obeidat 2016). This notwithstanding, it is unquestionable that major steps forward in the institutional prerogatives of judicial independence were made as a consequence of the events of 2011. It was high time for Jordan, as well as Morocco, to provide for an independent judicial institution with the prerogatives of promotion, appointment and evaluation detached from political will. However, it is noteworthy to stress that this will was specifically addressed by Arab legal practitioners and experts in the judicial field. An example of the call for judicially independent inspired reforms is the number of conferences at the regional level that have been organized addressing the issue of judicial independence. In particular, the Second Arab Conference on Justice in Cairo in 2003 is most significant; specifically, the conference noted the interference of the Executive power in judicial matters, impeding the true establishment of an independent judiciary.

With the constitutional reforms of 2011, we observe that Article 98 of the Constitution provides for the establishment of a Judicial Council with the power to appoint, promote, relocate, assign pensions without the interference of the Executive. The great crisis signalled by the 2011 protests and revolutions brought about significant reforms in the political system of Jordan, such as the establishment of the Constitutional Court, and saw the guarantees of independence strengthened through the creation of an independent Judicial Council (Interview 6). Moreover, by virtue of the amendment of Articles 58-61 the Constitutional Court was also established.

Public reactions to those milestone amendments were positive overall; the general consensus acknowledged the step made toward the respect of individual rights and the establishment of RoL. MPs saw the amendments as a much-needed radical change toward the strengthening of political will (Salameh and Ananzah 2015). Many criticisms however were made on the null change of power between the King, executive power, legislative and judiciary, underlining the strict control that the monarchy still exercises on judicial prerogatives. 
The table below illustrates the timing of the reforms that have concerned the judiciary in Jordan since King Abdullah's settlement. It is possible to observe how the EU began its support through the first Program of Judicial Support when Jordan was undergoing a major stream of efficiency-inspired reforms (notably JUST and National Agenda strategy). As the EU was engaged in supporting Jordan to meet international standards of quality of judicial administration, turmoil broke out across the whole region and, as a consequence of regional unrest and fear of neighbouring failing autocracies, the monarch encouraged a constitutional reform. The timing of the identification phase of the Program is specifically relevant since it happened in a period in which judicial support had to deal with a domestic context not oriented to tackle politically-driven reforms.

Table 2: Timeline, Jordan's judicial reforms and European inputs -here-

\section{Inputs: One program, five different components}

The Program of Judicial Support in Jordan, ‘Support to Justice Reform and Good Governance', with a budget of 6.8 million Euros and designed to assist Jordan's reform, consisted of five projects that were divided ideally into three main components: a) the component supporting the criminal justice reform process developed three differentiated projects, b) the component supporting the AntiCorruption Commission (ACC) for an effective implementation of an anti-corruption strategy in line with international standards with one project and c) a third component developed in one project directed to support and the Amman Message. The ENPI Program known as 'Support to Justice Reform and Good Governance in Jordan' can be considered the first significant external action of support strictly directed to the judicial sector in the country. The program has been characterized by a high variability in terms of actors engaged and objectives of singular projects as well as the means through which the inputs have been directed, but at the same time all the projects dealt with support given in drafting new laws and training experts (Interview 7).

In Contrast with Morocco, Jordan's EU programs of judicial support are differentiated and rely on a larger number of EU member states' expertise. 'Support to Juvenile Justice Reform in Jordan' was 
implemented by the United Nations Office on Drugs and Crime (UNODC), the project 'Support to Criminal Justice Reform in Jordan' was implemented by the United Kingdom through Northern Ireland Co-operation Overseas, while ‘Support to Penitentiary Reform in Jordan’ was implemented by France and Germany respectively through the JCI and the IRZ. The component on Anti-Corruption was implemented through a Twinning Project where Finland acted as member state leader, while the latter component on the Amman Message was implemented by the Royal Institute for Inter-Faith Studies of Amman; this last project is devoid of any European assessment report and therefore is not considered in further analysis.

\section{Championing legal drafting}

Under the umbrella Program four projects had a significant impact for what we define the administrative dimension of the judiciary, in particular for what concerns the aspect of legal accountability. The Project 'Support to Juvenile Justice Reform in Jordan' in fact consisted mostly of law revision strategies and training professionals; this project also had amongst its goals the direct delivery of technical facilities such a CCTV system for juvenile courts (Action Fiche 2012). The actions of the Juvenile Justice activities actually found a positive impact in the drafting of a new norm considered in line with international standards. Developments on the legal side were in fact positively recognized by international observers such as the International Labour Organization. The Law N. 32 of 2014 attained the standards of quality aligning Jordan to international standards by raising the minimum age of criminal responsibility from 7 to 12 ; it also prioritized alternatives to detention, adopting a rehabilitative approach to juvenile justice as opposed to a penal one (UNICEF 2014). The 2014 Law was also welcomed by the United Nations International Children's Emergency Fund (Ibid.), which stated that the new law generally allows for better protection for children who are in contact with the law. The new law on Juvenile Justice was also positively regarded by domestic experts such as the National Centre for Human Rights of Amman, which had for a long time advocated the need for legislative intervention in order to improve the law on Juvenile Justice. They had proposed draft amendments to the previous Law and positively encountered some of the provisions inserted in the 2014 Draft Law (NCHR 2014). 
The Project 'Support to Criminal Justice Reform in Jordan' implemented by the UK and Northern Ireland Cooperation Overseas (NICO) - a public body specializing in supporting public institutions through training, capacity building and consultancy to build efficient and accountable institutions (NiCo.org.uk) - is also regarded with significant domestic and international reactions. The amendment of the Criminal Procedure Code Art 158 that allows the use of materials recorded by audiovisual equipment at police stations as evidence in the courts and the Amendment to the Criminal Procedure in fact can be seen as a positive reaction of EU External support even if the actual passage of the amendments was not as smooth and direct as the Juvenile Justice Project. Indeed, only in 2017 a new law passed amending the Criminal Procedure Law of 1961.

In the meantime, Jordan went through parliamentary elections held in 2016 and the work of a new Royal Committee for Developing the Judiciary and enhancing Rule of Law recommended a package of reforms to criminal procedure law as well as the recommendations of international observers such as Human Rights Watch. The new amendments allow free-of-charge legal assistance for a wider range of crimes (JordanTimes.com 2017); moreover, the new law prohibits discrimination against people with disabilities (Ibidem). Article 308 of the Penal Code was also repealed regarding violence against women, while other changes include an increase in limits to pre-trial detention. Indeed, Legal Aid can be seen as the most notable change, both domestically and externally, and in this sense it follows the inputs of the EU-funded project. In fact, in 2012 a case study by the Justice Centre for Legal Aid- a Jordanian non profit organization- published a report addressing the need to intervene in Jordanians' legal access to justice (Justice Centre for Legal Aid); this report represented the most comprehensive data on access to justice in Jordan.

The Project ‘Support to Penitentiary Reform in Jordan' did not result in a direct legal change; only in the aftermath of the 2016 political elections did Parliament start discussing a set of amendments to the penal code that would provide for alternative penalties to prison (JordanTimes 2016). This notwithstanding, the project developed by the German organization IRZ in cooperation with the French Justice Cooperation Internationale (JCI) focused on a few main axes such as the development of the structure and management of the Correctional Centre and Reinsertion Department (CRCD), the 
promotion of cooperation with the Ministry of Justice in the framework of the penitentiary reform and the installation of new systems and equipment.

'Support the Anti-Corruption Commission' (ACC) consisted of a project that supported the government to implement the National Anti-Corruption Strategy of Jordan 2013-2017. The Project was developed through a Twinning where the European supply side was represented by Finland's HAUS agency. The Twinning project began in 2011 on demand of the Ministry of Justice within the framework of a call for the enforcement of an anti-corruption regime by King Abdullah II. The Project came out with a detailed action plan that set out to strengthen the capacity of the AntiCorruption Commission of Jordan. In 2016 the Integrity and Anti-Corruption Commission (IACC) came into force along with an update in the anti-corruption law, adding definitions of criminal offences and improving the protection of witnesses and informants (Interview 6). The Anti-Corruption Commission (ACC) was merged with the Ombudsman's office, becoming the Jordanian Integrity and Anti-Corruption Commission (JIACC).

A discrete amount of European practices and norms appealed to Jordanian politicians who saw in the models offered not only a way to strengthen the efficiency of the judiciary and judicial institutions but also a way to ease the link with international donors. It must be noted that a substantial new EU Program of Judicial Support has been approved for Jordan in 2018- a structured one as it consists of a Budget Support Program that is going to direct funding to the Ministry of Finance in Jordan. This brand new program also confirms the hypothesis raised for the case of Morocco that a package of reforms is also undertaken as an anticipation of further cooperation.

On the reception and implementation side, the project on Criminal Justice Reform and Penitentiary Reform has been actively implemented. The first milestone result is the creation of a 'National Committee on Criminal Justice'; the project had a positive reception among domestic actors and saw the participation of both civil society groups and the Bar Association (UNODC 2018). The program overall can be regarded as successful if the specific micro-objectives of each project are taken into consideration. Indeed, it was specifically designed in line with the EU Jordan National Indicative Program of 2007-2010. The main issues recognized by the EU in 2007 were particularly addressed toward the capacity-gap of public administration in general, and in particular of judicial governance to 
implement reforms; in this way, the orientation of the cooperation has been greatly directed towards the performance of the service and good governance (EU Strategy Paper 2007).

The copying of norms - or parts of - does not provide for a change of institutional legitimacy but conversely is positively received by civil society as well as practitioners, representing a win-win game for both donors and beneficiary. The enhancement of the capacity of Anti-Corruption centres and new laws meeting international standards of child protection can be seen as a success story in terms of judicial reform in Jordan. The EU had supported anti-corruption efforts by the government and the King, as well as law drafting that would provide for efficient legal procedures and, as a consequence, the improvements on the administrative dimension happened throughout the pre- and post-2011 reform agenda. In this case, European socialization worked for a reason. The adoption of new legislation concerning Criminal law, Legal Aid and Anti-Corruption met the political agenda of the government and the willingness of the King to create a more transparent, functioning and accountable judiciary.

\section{Comparative Assessment}

Our initial question was to assess whether the external support of the EU, through a number of programs and single projects directed toward Morocco and Jordan in the past decade, was able to enter their domestic systems, in particular in the aftermath of the main constitutional reforms of 2011 in Jordan and Morocco. We maintained that external judicial models were able to penetrate domestic systems only to a certain extent and thus, operationalizing judicial support in institutional and administrative dimensions, we maintained that the institutional-systemic-level reforms would have been domestically driven due to the high political costs associated with this particular dimension, such as for instance the establishment of stronger guarantees of judicial independence. The empirics confirm our initial hypothesis and the comparative analysis adds that reforms undertaken at the systemic level were not only domestically driven but followed a path dependent effect. Conversely, the two beneficiary countries were able to fully exploit EU-funded programs of efficiency-inspired reform support. 
The countries chosen for this analysis share a number of similarities but differ on the institutional set-up of their judicial system; notably, the two countries shared a common feature among other elements. Both monarchies had to come to terms with the need to reform their judiciaries; in particular, popular demands asked for a more independent and efficient judiciary able to tackle widespread corruption. The EU supported those claims with programs specifically designed to strengthen judicial independence and efficiency; however, what we observe is a significant differentiation of the reforms enacted in the two countries.

We maintain that a great deal of explanation can be better grasped if judicial reforms are divided into institutional and administrative. From the empirical findings we maintain that: 1) while the EU offered support to the judicial reforms, the two beneficiary countries aptly engaged in programs that tackled the administrative dimension more than the institutional. This can be explained by the rationalist approach that underlines the high political costs that institutional reforms encounter vis à vis the non-systemic administrative dimension; 2) the institutional dimension followed a path dependent effect; we encounter the same differences of the pre-constitutional reforms status quo, thus the pre-reform legacies were maintained.

Despite being two liberalizing democracies and representing the two most similar cases of the Southern Mediterranean Region, Morocco and Jordan differ to the extent to which their Monarchies retained power and, most importantly, were able to maintain prerogatives throughout 2011's main reforms.

In 2011 Morocco adopted a new Constitution that opened the way to a judicial reform that finally established an independent institution, with the constitutional provision of 2011, a big leap forward for the establishment of fundamental guarantees of judicial independence, a development that Morocco had never experienced before 2011. The King maintains the presidency of the CSPJ but, by Royal Decree, established a number of guarantees that were not present before; this was not the case for Jordan.

Jordan's history is more one of monarchical power than Morocco's (Burgis 2007), at least in relation to the King's prerogatives over the executive power. Indeed, Jordan's 2011 constitutional reforms did not represent a major turning point for judicial independence since the Law on Judicial 
Independence - JIL - was already adopted in 2001 establishing, de jure but not with an organic law, the High Judicial Council that was then only later inserted in the Constitution within the 2011 reform. These distinctive features of the 2011 constitutional reforms, the establishment of a number of judicial independence guarantees in Morocco vis à vis a continuity with the former institutional setting, are maintained throughout the process of externally supported judicial reforms. See the table below for the institutional shifts.

Even if the two countries followed a mostly similar course of events in 2011, specifically with the constitutional reforms that should have put checks on the unlimited powers of the monarchies and the executives hence opening the way to protesters and political opposition, their institutional judicial path is significantly different. The comparative analysis allows us to trace those differences as the effect of past legacies. A major difference can be observed in the quota of power shared between the King and government in the two countries that is hereafter taken into account.

Table 3: Morocco and Jordan in comparative perspective. The institutional dimension -here-

\section{A matter of power}

The Moroccan Constitution of 1996 allowed the King to have full control over the executive power; in particular, the Prime Minister was appointed at the King's discretion. With the 2011 reform, the Sovereign appoints the Prime Minister according to the party that won the election, as in the 2016 election when the King appointed Benkirane, leader of the winning coalition party. It signifies, as a matter of fact, a process of power sharing between the Sovereign and the executive power as resulting from the 2011 constitutional reform. This notwithstanding, Morocco is not transformed into a parliamentary monarchy, where the prerogatives of the King are limited by the legislative, but is an executive monarchy with a 'bicephalous executive' where one head is the King who remains the ultimate leader of the country (Biagi 2018: 387).

The Amendments that marked the 2011 constitutional reform process in Jordan are much more limited if compared with the reforms in Morocco. While it is true that in 2011 the King lost some 
power, in particular the ability to control the elections and lost the power to postpone elections, His Majesty's prerogatives remain overall unaltered. In particular, in the constitutional amendments of 2014 and 2016 we observe the strengthening of power of the King vis à vis the executive. The King now appoints, among others, the President of the Judicial Council, the President and members of the Constitutional Court (thereof established only in 2011) without the countersignature of the Prime Minister nor the Minister of Justice.

While Morocco became even more of an executive monarchy, Jordan turned into a presidential monarchy where the powers of the executive are even more limited by the King's prerogatives when compared to the past (Biagi 2018: 389). We maintain that the different distribution of power that emerged as a consequence of the main constitutional reforms of 2011 explains the different ways in which the institutional dimension of the judiciary is set out.

\section{Net gains and successfully endorsed external models}

The comparative assessment of Jordan and Morocco's court modernization reforms suggests an interestingly similar pattern, indeed a consistent reform of the Judicial Academy, in particular with new curricula and facilities in Morocco and the adoption of court management tools in Jordan having been positively endorsed. The changes that pertain to the administrative dimension in fact respond to a different logic. The observation of the changes introduced by Morocco and Jordan in the judicial administrative dimension that pertains to a low politics area if compared to the institutional dimension, supports our initial hypothesis that expected an impact where no political costs associated to rule adaptation are encountered. Moreover, we observe an uneven distribution of administrative reforms between the two countries. We maintain that this is the effect of the nature and design of the programs and single projects the EU uses in the JHA realm. This is indeed an innovative observation that fills a gap in the empirical analysis of external normative pressure (Schimmelfennig and Sedelmeier 2005) that has never focused in depth on the programs of JHA of the EU towards the Southern ENP.

The evidence gathered from mapping the JHA support in the two most similar cases of the Southern Mediterranean showed indeed significant similarities. The EU acted in the same manner 
with Morocco and Jordan, the two countries both being 'good neighbourhoods' since the commencement of the European Mediterranean policy; both Morocco and Jordan have negotiated and agreed on an Action Plan that provides for an independent and efficient judiciary for the establishment of the rule of law. The European programs and single projects that are encountered in this analysis show how the European action of judicial support is specifically designed around the needs expressed by the singular donor; this also provides an access to member states' experts and best practices transmitted through epistemic communities- to enter the domestic systems through the empowering of change agents.

The administrative dimension consists of low or null costs in terms of loss of power for veto players and we assume that to a great extent those reforms were perceived from the outset as a gain in Morocco and Jordan. As Morlino and Magen posited, a cost-benefit analysis has been made and the reforms have been easily accepted (Morlino and Magen 2008: 234). A glimpse at the administrative dimension-related changes is evidence of how socialization works even in the absence of conditionality. Conversely, where the political costs for change are high the likelihood of change, in particular in the absence of strong conditionality, is null.

\section{Conclusion}

From a comparative analysis it emerges that the guarantees of independence are not established in the same manner. This is an interesting variation deserving further investigation. The empirics support the comparative literature's stance that had previously engaged in the question of the impact that externally driven models of democracy have in beneficiary countries. In particular, our case studies deal with the peculiar condition of the absence of credible EU conditionality and membership perspective, weak material incentives and economic linkages if compared to the studies on eastern enlargement (Schimmelfennig and Sedelmeier 2005; Vachudova 2005). Moreover, drawing upon the comparative literature we expected that the impact of externally promoted judicial models would be less complete (Morlino and Magen 2008). Indeed, from the comparative assessment of the institutional dimension of the judiciary in Jordan and Morocco we are keen to support our hypothesis. 
Our evidence is supporting the rationalist approach of resistance to changes as regards the institutional dimension of the judiciary, nonetheless even in the absence of external conditionality our evidence sheds light on a successful way in which external support for reforms enters the domestic systems. In line with what scholars have shown, our empirics also demonstrate that where there is no resistance of veto players to prevent a reform, and even in the absence of clear external conditionality, the administrative dimension of beneficiary countries is open to change (Morlino and Magen, 2008; Börzel 2011, Börzel and Risse 2012).

Interviews

Interview 1: Paolo Gozzi, DG Enlargement- coordinator Twinning instrument, Brussels

Interview 2: Madame Frieh-Chevalier, director EUD in Morocco

Interview 3: Axel Gamet, director Justice Coopération Internationale, Paris

Interview 4: Elise Zahi, project manager Justice Coopération Internationale, Paris

Interview 5: Hugo Plailly, Delegation international and European Affairs, Ministry of Justice of France

Interview 6: Judge Dr Mohammed Gazwi, former member of the Jordanian Constitutional Court Interview 7: Dr. Giorgio Giorgi, European Union Delegation in Jordan

\section{References}

Al-Marzouki Y. 2016. 'Reforming the Judiciary in Morocco. A Compiled Report' in Arab Reform Initiative Justice in Morocco.

Biagi F. 2018. 'The Separation of Powers and Forms of Government in the MENA Region following the "Arab Springs": a Break with the Past?' Diritto Pubblico Comparato ed Europeo, Il Mulino Fascicolo 2.

Börzel T. 2011 'When Europe hits... beyond its borders: Europeanization and the near abroad' Comparative European Politics, 9(4): 394-413 
Börzel, T., Risse T. 2012 ‘From Europeanization to Diffusion: Introduction’ West European Politics, 35(1): $1-19$

Burgis M.L 2007. 'Judicial Reform and the Possibility of Democratic Rule of Law in Jordan: A policy Perspective on Judicial Independence.' Arab Law Quarterly 21(2):135-169.

Capano G. 2003 'Administrative Traditions and Policy Change: When Policy Paradigms Matter. The Case of Italian Administrative Reform During the 1990s' Public Administration, 81(4): 781-801.

Cobb Roger, Ross Jennie-Keith, and Marc Howard Ross 1976. 'Agenda Building as a Comparative Political Process', The American Political Science Review 70(1): 126-138.

European Commission Strategy Paper 2007-2013 Jordan, https:/ec.europa.eu/europeaid/sites/devco/files/csp-nip-jordan-2007-2013 en.pdf

European Commission 2005. 'EU/Jordan ENP Action Plan.' http: library.euneighbours.eu

European Commission 2008. ‘Action Fiche for Jordan.'Accessed June, 2018

https://ec.europa.eu/europeaid/support-justice-reform-and-good-governance-jordan-action-fiche en

European Commission 2011. 'Morocco Progress Report' http: library.euneighbours.eu

European Commission 2012, ‘Action Fiche for Jordan’ http: library.euneighbours.eu

Feldman, Noah 2008. Fall and Rise of the Islamic State. Princeton University Press.

Finnemore M, Sikkink K 1998 'International Norm Dynamics and Political Change.' International Organization at fifty: exploration and contestation in the study of world politics. 52(4): 887-917.

Gawrich A., Melnykovska I., Schweickert R. 2009 'Neighbourhood Europeanization through ENP, the case of Ukrain' KFG Working Paper N.3.

Grabbe, Heater 2004. The EU's Transformative Power Europeanization through Conditionality in Central and Eastern Europe. Palgrave Macmillan.

ICJ International Commission of Jurists 2015. Morocco flawed draft laws on High Judicial Council, http:www.ICJ.org.

JCI Justice Coopération Internationale 2017. Rapport d'Activité. French Ministry of Justice.

King Mohammed VI Royal Speech 20 August 2009, Accessed May 1, 2018 http: www.maroc.ma

Lavenex S., Schimmelfennig F. 2008 'Relations with the Wider Europe' Journal of Common Market Studies, Vol 46: 145-164

Magen Amichai, Morlino Leonardo 2008. International Actors, Democratization and the Rule of Law: Anchoring Democracy? Routledge/UACES. 
Ministry of Justice of Jordan 2014-2015 ‘ Strategic Plan.’ Accessed June, 2018: https://rm.coe.int/jordanian-ministry-of-justice-strategy-2014-2016/168078a8b8

Natorski, M. 2008 'The Meda programme in Morocco 12 years on: results, experiences and trends' CIDOB Mediterraneo: 11.

NCHR 2014 'Juvenile Criminal Justice in Jordan’ Accessed online June 3, 2018 http://www.nchr.org.jo/Admin_Site/Files/PDF/f548f5e8-a245-4abd-91ac-c9fe68aa1bf1.pdf

Obeidat S. 2016. 'Jordan's 2016 Constitutional Amendments: A Return to Absolute Monarchy?' ConstitutionalNet, 27 May 2016.

O'Sullivan D. 1999 'Gender Equity as Policy Paradigm in the Irish Educational Policy Process' The Economic and Social Review: 3.

Piana D. 2009 'The Power Knocks at the Courts' Back Door: Two Waves of Postcommunist Judicial Reforms.' Comparative Political Studies 42 (6): 816-840.

Russell Peter H. and O'Brien David M. 2001. Judicial Independence in the Age of Democracy, Critical Perspectives from Around the World. Charlottesville: University Press of Virginia.

Salameh M.T.B, and Ananzah A.A 2015. 'Constitutional Reforms in Jordan: A critical Analysis' Digest of Middle East Studies, 24(2): 139-160.

Sasse, G 2008 'The Politics of EU conditionality: the norm of minority protection during and beyond EU accession' Journal of European Public Policy, 15(6): 842-860.

Schimmelfennig F., Sedelmeier U. 2005. The Europeanization of Central and Eastern Europe. Cornell University Press.

Terms of Reference 2015. Assistance technique auprès du ministere de la justice. French Ministry of Justice.

The Jordan Times, April 17, 2016 'Amended Penal Code to enforce rule of law' http://www.jordantimes.com/news/local/amended-penal-code-enforce-rule-law\%E2\%80\%99

The Jordan Times, September 9, 2017 ' Criminal Procedure Law Amendments endorsed' http://www.jordantimes.com/news/local/criminal-procedure-law-amendments-endorsed\%E2\%80\%94-justice-minister

The World Bank Legal Vice Presidency 2003. Morocco Legal and Judicial Sector Assessment. Accessed May 10, 2018 http: worldbank.org.

The World Bank Legal Review 2014. Fostering Development through Opportunity, Inclusion and Equity, edited by H.Cissé, N.R.M. Menon, M.C Cordier Segger, and V.O. Nmehielle. Vol 5. 
Tsebelis G. 1995 'Decision Making in Political Systems: Veto Players in Presidentialism,

Parliamentarism, Multicameralism and Multipartyism' British Journal of Political Science, 25(3):289325

UNICEF 2014 'Annual Report' Accessed online June 3, 2018

https://www.unicef.org/about/annualreport/files/Jordan_Annual_Report_2014.pdf

UNODC, Amman January 2018 https://www.unodc.org/middleeastandnorthafrica/en/web-

stories/jordan -a-solid-partnership-to-strengthen-justice-for-children-and-criminal-investigation.html

Vachudova M.A 2005. Europe Undivided: Democracy,Leverage and Integration after Communism. Oxford: Oxford University Press.

Voermans W. 1999. Councils for the Judiciary in EU countries. European Commission/TAIEX (Accessed, March 19,2019)

Zaatit H. 4 Avril 2018 'La Tribune Politique.' Accessed May 1, 2018 https://lnt.ma/1ere-anneeconseil-superieur-pouvoir-judiciaire-bilan-de-mostafa-fares/

Tables:

Table 1

\begin{tabular}{|c|c|c|}
\hline Date & Judicial Reforms in Morocco & European Inputs \\
\hline Pre-2011 & $\begin{array}{ll}\text { - } & \text { Civil Society, Political } \\
\text { Activists call for } \\
\text { comprehensive Judicial } \\
\text { Reforms } \\
\text { - New Legislation: Trade } \\
\text { law, Competition law, } \\
\text { Commercial Courts law, } \\
\text { Industrial Properties law } \\
\\
\text { - The King calls for } \\
\text { Constitutional Review } \\
\text { - Creation Consultative } \\
\text { Commission for } \\
\text { - Constitutional Revision } \\
\text { - Chapter 7 Revised } \\
\text { Creation CSPJ }\end{array}$ & $\begin{array}{l}\text { 18 March 2000: EU } \\
\text { Association Agreement } \\
\text { signed with Kingdom of } \\
\text { Morocco }\end{array}$ \\
\hline & $\begin{array}{l}\text { Passing Organic Law } \\
\text { CSPJ }\end{array}$ & $\begin{array}{l}\text { 2014: 'Programme } \\
\text { d'appui sector de la } \\
\text { Justice', conditionality for } \\
\text { disbursement: CSPJ, } \\
\text { Statut Magistrates }\end{array}$ \\
\hline
\end{tabular}




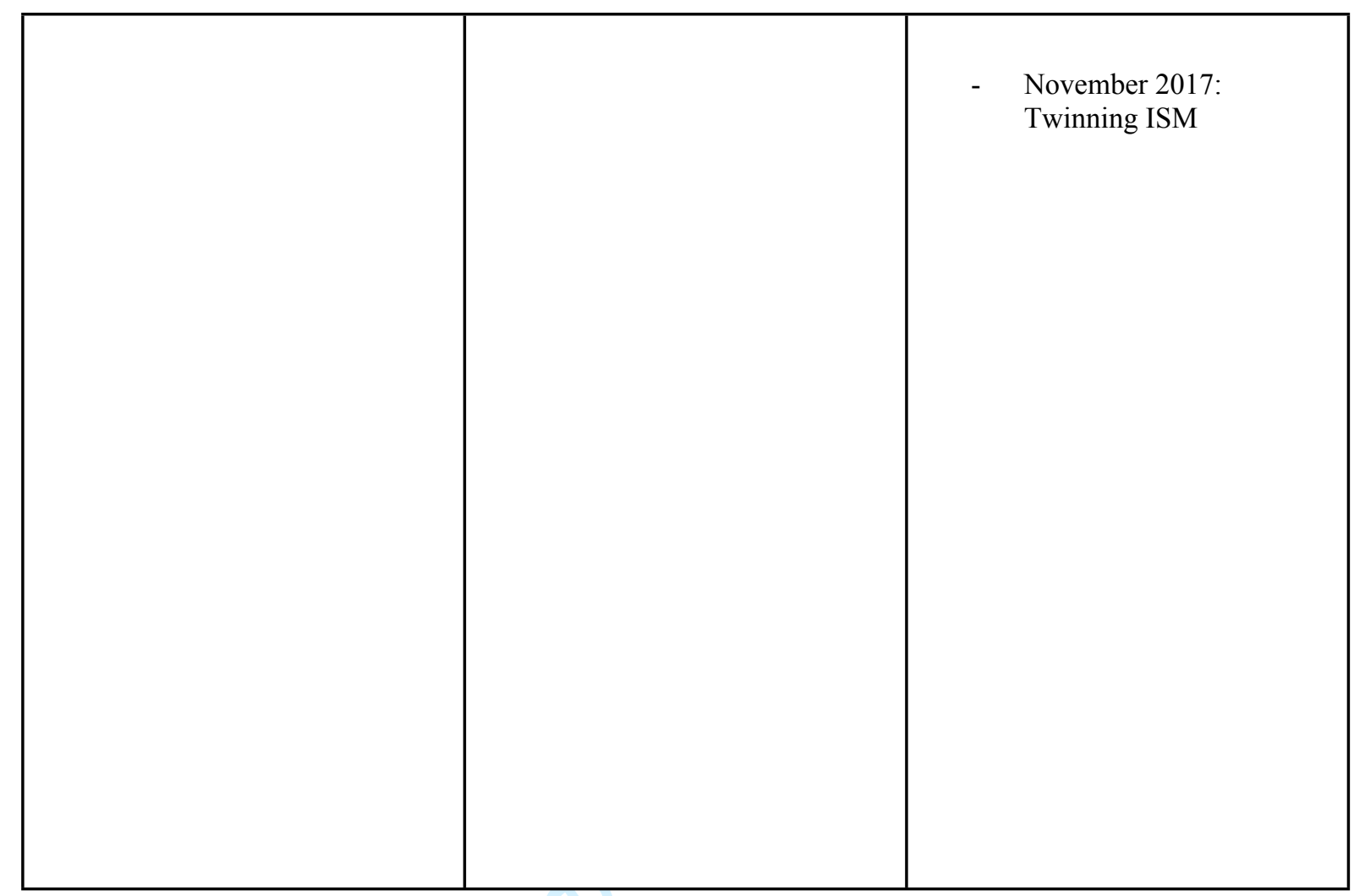

EU: European Union, CSPJ: Conseil Supérieur du Pouvoir Judiciaire, ISM: Institut Supérieur de la Magistrature

Table 2

\begin{tabular}{|l|l|l|}
\hline Date & $\begin{array}{l}\text { Judicial Reforms in } \\
\text { Jordan }\end{array}$ & European Inputs \\
\hline
\end{tabular}




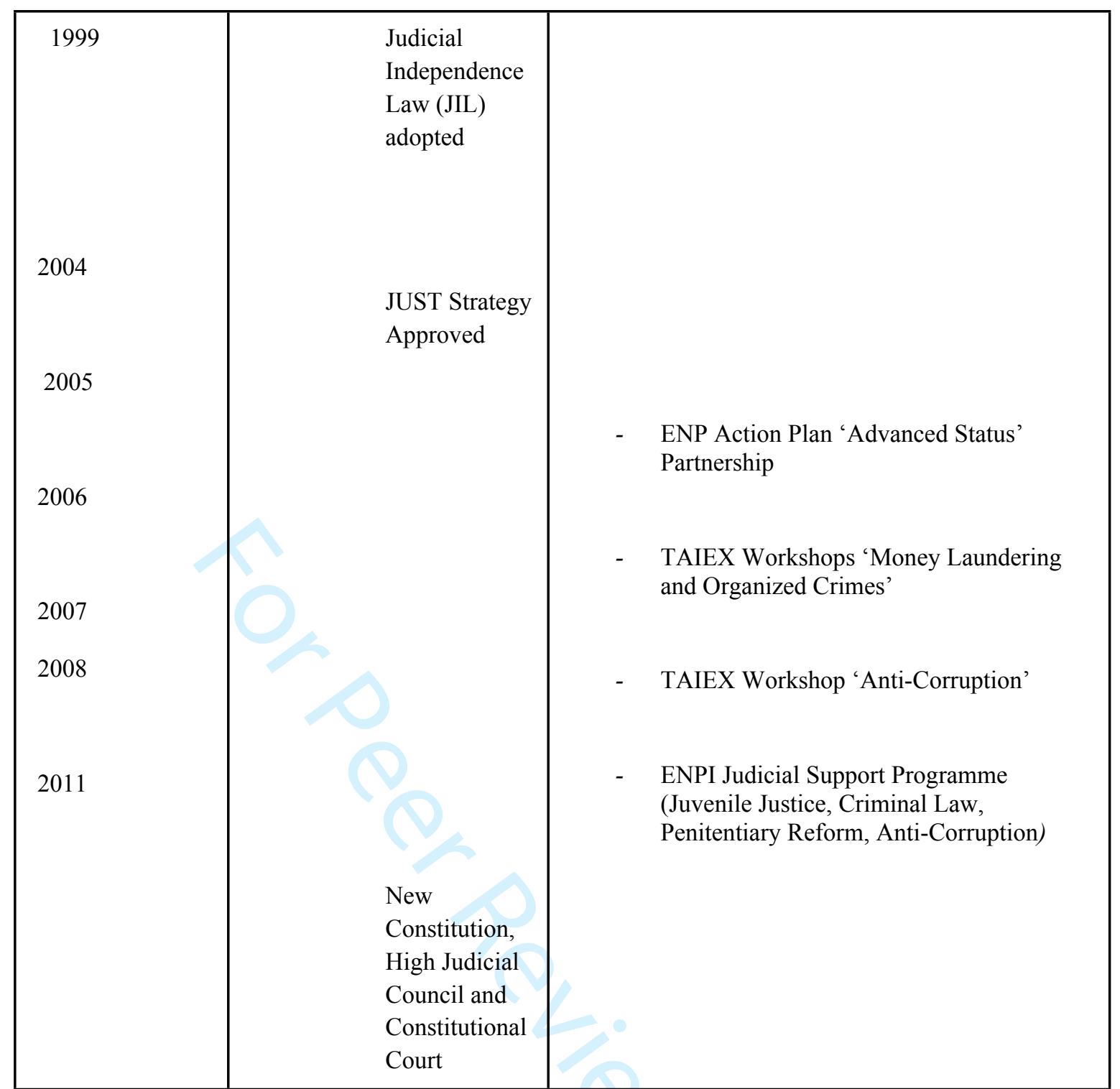

ENP: European Neighbourhood Policy, TAIEX: Technical Assistance and Information Exchange, ENPI: European Neighbourhood Policy Instrument, JIL: Judicial Independence Law

Table 3

\begin{tabular}{|l|l|l|}
\hline MOROCCO & \multicolumn{2}{|c|}{ JORDAN } \\
$\mathrm{T} 0$ & $\mathrm{~T} 1$ & $\mathrm{~T} 0$ \\
\hline
\end{tabular}




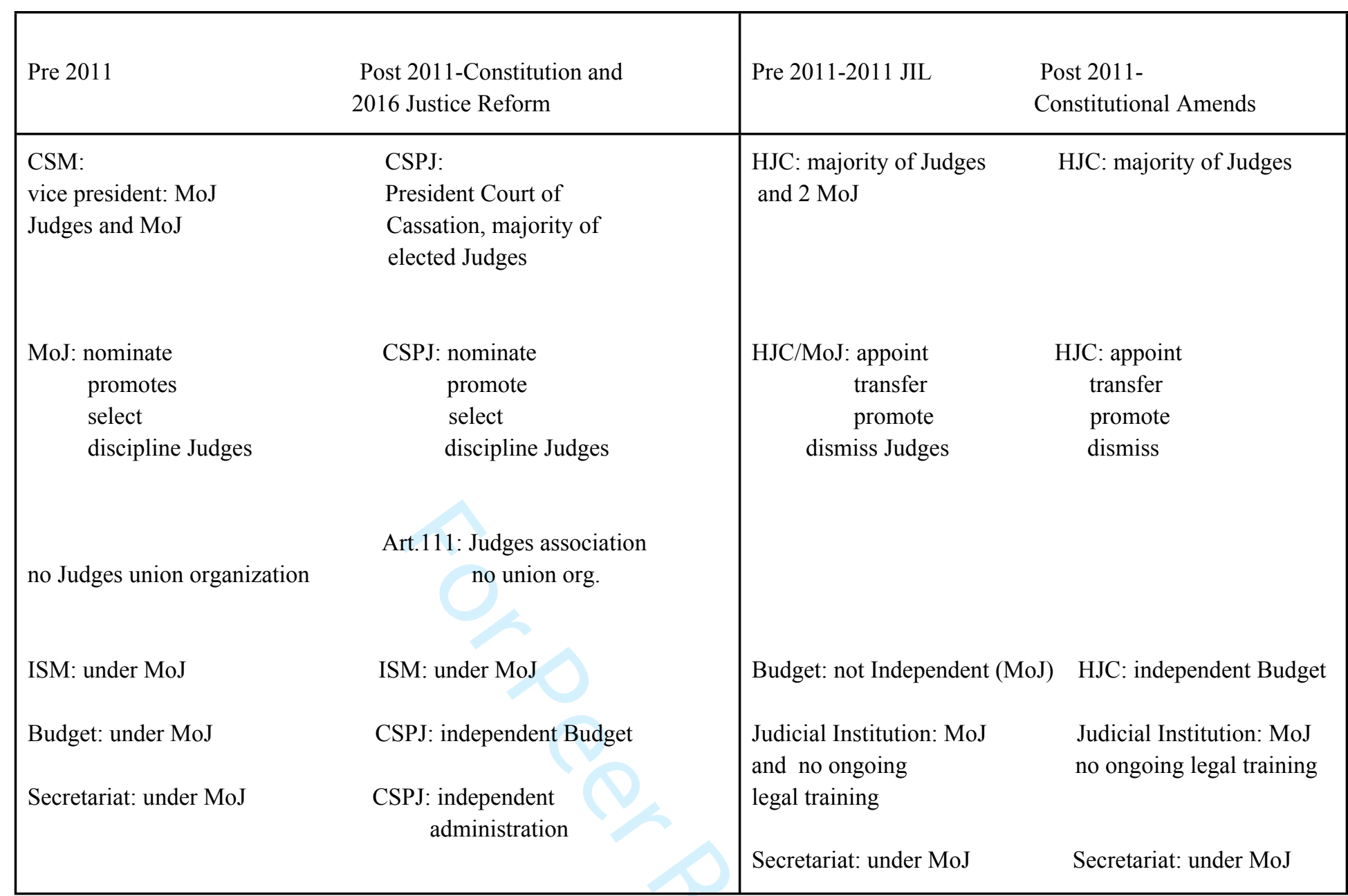

MOJ: Ministry of Justice, JC: Judicial Council, CSM: Conseil Supérieur de la Magistrature, ISM: Institut Supérieur de la Magistrature, CSPJ: Conseil Supérieur du Pouvoir Judiciaire 
Tables:

Table 1

\begin{tabular}{|c|c|c|}
\hline Date & Judicial Reforms in Morocco & European Inputs \\
\hline (1) & $\begin{array}{ll}\text { - } & \text { Civil Society, Political } \\
\text { Activists call for } \\
\text { comprehensive Judicial } \\
\text { Reforms } \\
\text { - New Legislation: Trade } \\
\text { law, Competition law, } \\
\text { Commercial Courts law, } \\
\text { Industrial Properties law } \\
\text { - } \\
\text { The King calls for } \\
\text { Constitutional Review } \\
\text { - Creation Consultative } \\
\text { Commission for } \\
\text { - Constitutional Revision } \\
\text { - Chapter 7 Revised } \\
\text { Creation CSPJ }\end{array}$ & $\begin{array}{l}\text { 18 March 2000: EU } \\
\text { Association Agreement } \\
\text { signed with Kingdom of } \\
\text { Morocco }\end{array}$ \\
\hline \multirow{2}{*}{ March 2011} & $\begin{array}{l}\text { Passing Organic Law } \\
\text { CSPJ }\end{array}$ & $\begin{array}{l}\text { 2014: 'Programme } \\
\text { d'appui sector de la } \\
\text { Justice', conditionality for } \\
\text { disbursement: CSPJ, } \\
\text { Statut Magistrates }\end{array}$ \\
\hline & & $\begin{array}{l}\text { - November 2017: } \\
\text { Twinning ISM }\end{array}$ \\
\hline
\end{tabular}

EU: European Union, CSPJ: Conseil Supérieur du Pouvoir Judiciaire, ISM: Institut Supérieur de la Magistrature 
Table 2

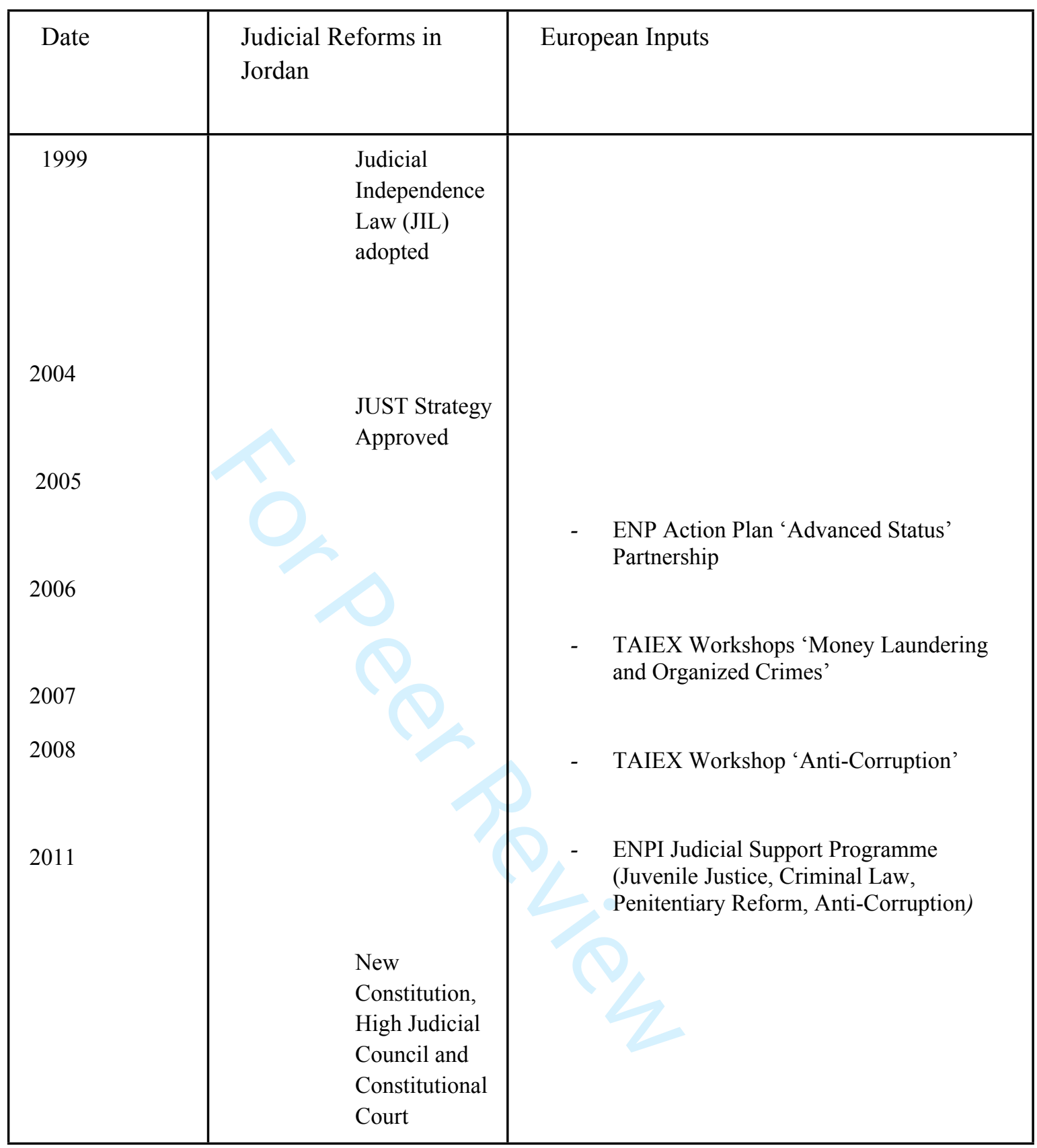

ENP: European Neighbourhood Policy, TAIEX: Technical Assistance and Information Exchange, ENPI: European Neighbourhood Policy Instrument, JIL: Judicial Independence Law 
Table 3

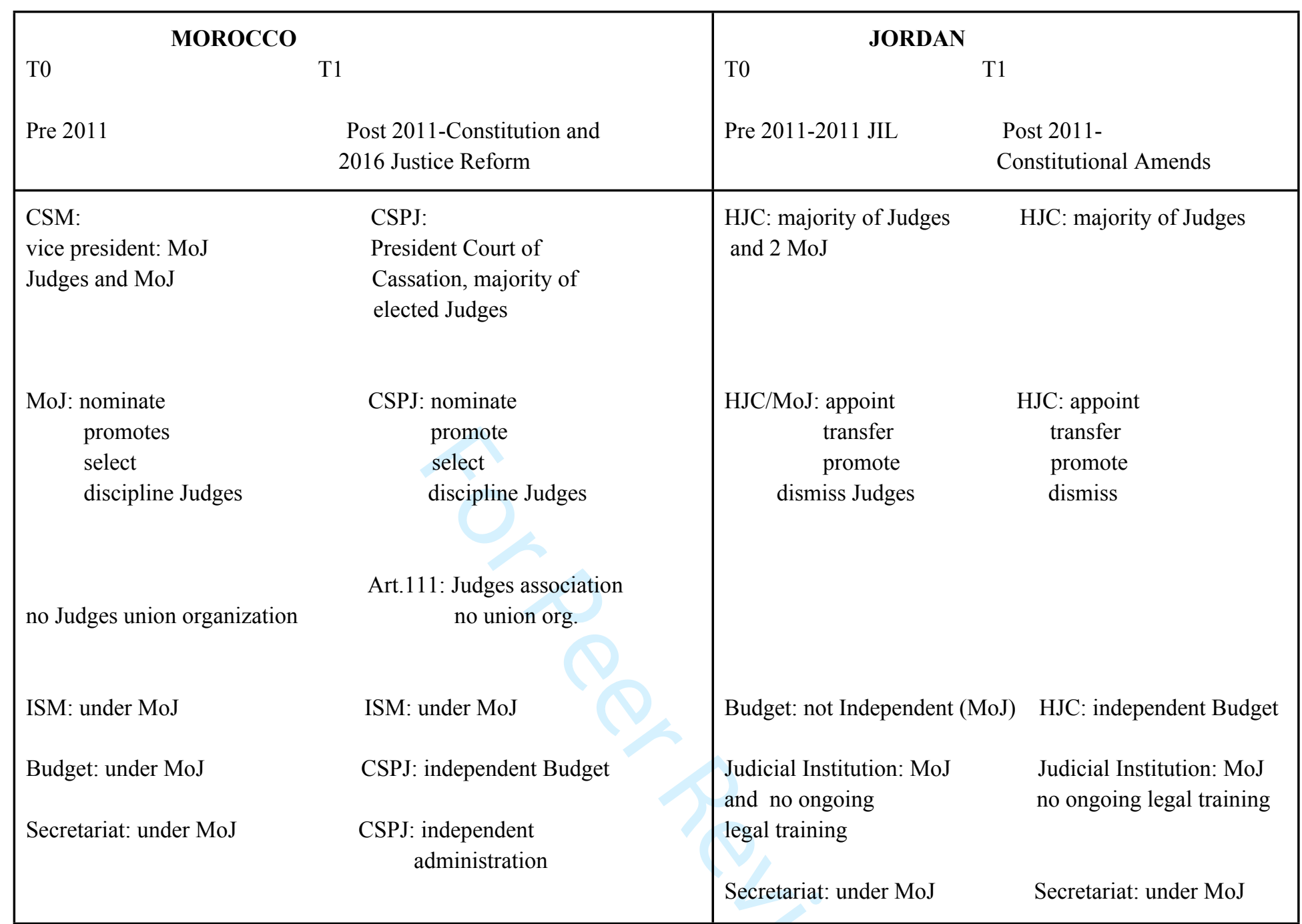

MOJ: Ministry of Justice, JC: Judicial Council, CSM: Conseil Supérieur de la Magistrature, ISM: Institut Supérieur de la Magistrature, CSPJ: Conseil Supérieur du Pouvoir Judiciaire 